\title{
Amendments to saline-sodic soils showed long-term effects on improving growth and yield of rice (Oryza sativa L.)
}

\author{
Dandan Zhao ${ }^{1,2}$, Zhichun Wang ${ }^{\text {Corresp., } 1}$, Fan Yang ${ }^{\text {Corresp., } 1}$, Wendong Zhu ${ }^{1,2}$, Fenghua An ${ }^{1}$, Hongyuan Ma ${ }^{1}$, Tibor Toth \\ ${ }^{3}$, Xu Liao ${ }^{1}$, Hongtao Yang ${ }^{1}$, Lu Zhang ${ }^{1}$ \\ ${ }^{1}$ Northeast Institute of Geography and Agroecology, Chinese Academy of Sciences (CAS), Changchun, China \\ 2 University of Chinese Academy of Sciences, Beijing, China \\ 3 Research Institute for Soil Science and Agricultural Chemistry of the Hungarian Academy of Sciences, Budapest, Hungary \\ Corresponding Authors: Zhichun Wang, Fan Yang \\ Email address: wangzhichun@iga.ac.cn, yangfan@iga.ac.cn
}

Background. Saline-sodic soils are widely distributed in arid and semi-arid regions around the world. High levels of salt and sodium inhibit the growth and development of crops. However, there has been limited reports on both osmotic potential in soil solutions $\left(\mathrm{OP}_{\mathrm{ss}}\right)$

and characteristics of $\mathrm{Na}^{+}$and $\mathrm{K}^{+}$absorption in rice in saline-sodic soils under various amendments application. Methods. A field experiment was conducted between 2009 and 2017 to analyze the influence of amendments addition to saline-sodic soils on rice growth and yield. Rice was grown in the soil with no amendment (CK), with desulfurization gypsum (DG), with sandy soil (SS), with farmyard manure (FM) and with the mixture of above amendments (M). The osmotic potential in soil solution, selective absorption of $\mathrm{K}^{+}$over $\mathrm{Na}^{+}$ (SA), selective transport of $\mathrm{K}^{+}$over $\mathrm{Na}^{+}(\mathrm{ST})$, the distribution of $\mathrm{K}^{+}$and $\mathrm{Na}^{+}$, and yield components in rice plants were investigated. Results. The results indicated that amendments application have positive effects on rice yield. The $M$ treatment was the best among the tested amendments with the highest rice grain yield. $M$ treatment increased the $\mathrm{OP}_{\mathrm{ss}}$ values significantly to relieve the inhibition of the water uptake by plants.

Additionally, the $\mathrm{M}$ treatment significantly enhanced $\mathrm{K}^{+}$concentration and impeded $\mathrm{Na}^{+}$ accumulation in shoots. SA values were reduced while ST values were increased for all amendments. In conclusion, a mixture of desulfurization gypsum, sandy soil and farmyard manure was the best treatment for the improvement of rice growth and yield in the Songnen Plain, northeast China. 


\section{Amendments to saline-sodic soils showed long-term}

3 effects on improving growth and yield of rice (Oryza

4 sativa L.)

5

6

7 Dandan Zhao ${ }^{1,2}$, Zhichun Wang ${ }^{1 *}$, Fan Yang ${ }^{1 *}$, Wendong Zhu ${ }^{1,2}$, Fenghua An ${ }^{1}$, Hongyuan Ma ${ }^{1}$,

8 Tibor Toth $^{3}, \mathrm{Xu} \mathrm{Liao}^{1}$, Hongtao Yang ${ }^{1}$, Lu Zhang ${ }^{1}$

1 Northeast Institute of Geography and Agroecology, Chinese Academy of Sciences (CAS), China, Changchun 130102, (China)

2 University of Chinese Academy of Sciences, Beijing 100049, (China)

3 Research Institute for Soil Science and Agricultural Chemistry of the Hungarian Academy of Sciences, Herman Otto 15, H-1525 Budapest, (Hungary)

\section{Corresponding Author:}

Zhichun Wang, Fan Yang

Shengbei Street No. 4888, Changchun city, Jilin Province, 130102, China

Email address: wangzhichun@iga.ac.cn

\section{Abstract}

Background. Saline-sodic soils are widely distributed in arid and semi-arid regions around the world. High levels of salt and sodium inhibit the growth and development of crops. However, there has been limited reports on both osmotic potential in soil solutions $\left(\mathrm{OP}_{\mathrm{ss}}\right)$ and characteristics of $\mathrm{Na}^{+}$and $\mathrm{K}^{+}$absorption in rice in saline-sodic soils under various amendments application.

Methods. A field experiment was conducted between 2009 and 2017 to analyze the influence of amendments addition to saline-sodic soils on rice growth and yield. Rice was grown in the soil with no amendment (CK), with desulfurization gypsum (DG), with sandy soil (SS), with farmyard manure (FM) and with the mixture of above amendments (M). The osmotic potential in soil solution, selective absorption of $\mathrm{K}^{+}$over $\mathrm{Na}^{+}(\mathrm{SA})$, selective transport of $\mathrm{K}^{+}$over $\mathrm{Na}^{+}(\mathrm{ST})$, the distribution of $\mathrm{K}^{+}$and $\mathrm{Na}^{+}$, and yield components in rice plants were investigated. 
32 Results. The results indicated that amendments application have positive effects on rice yield. The $\mathrm{M}$ treatment was the best among the tested amendments with the highest rice grain yield. M treatment increased the $\mathrm{OP}_{\mathrm{ss}}$ values significantly to relieve the inhibition of the water uptake by plants. Additionally, the $\mathrm{M}$ treatment significantly enhanced $\mathrm{K}^{+}$concentration and impeded $\mathrm{Na}^{+}$ accumulation in shoots. SA values were reduced while ST values were increased for all amendments. In conclusion, a mixture of desulfurization gypsum, sandy soil and farmyard manure was the best treatment for the improvement of rice growth and yield in the Songnen Plain, northeast China.

Abbreviations: $\mathrm{OP}_{\mathrm{ss}}$, osmotic potential in the soil solution, bars; $\mathrm{SA}$, selective absorption of $\mathrm{K}^{+}$over $\mathrm{Na}^{+}$; ST, selective transport of $\mathrm{K}^{+}$over $\mathrm{Na}^{+}$; EC, electrical conductivity in 1: 5 soil to water extracts, $\mathrm{dS} \mathrm{m}^{-1}$; SOC, soil organic carbon, $\mathrm{g} \mathrm{kg}^{-1}$; CK, control, without amendments application; DG, desulfurization gypsum; SS, sandy soil; FM, farmyard manure; M, mixture of desulfurization, sandy soil and farmyard manure.

\section{Introduction}

Soil salinity-sodicity is one of the main impediments for crop productivity and sustainability in arid and semiarid areas (Suarez, 2001; Qadir et al., 2006). Saline-sodic soils comprise approximately $3.67 \times 10^{7}$ ha, and Songnen Plain is one of the major saline-sodic areas in China (Yao et al., 2008; Yang et al., 2016). $\mathrm{pH}$ stress and $\mathrm{Na}^{+}$toxicity are the main causes of the degradation in saline-sodic soils (Gharaibeh et al., 2010). Efforts have been made to ameliorate saline-sodic soils including desulfurization gypsum, farmyard manure, sand, hydraulic engineering and phytoremediation (Qadir et al., 2007; Wang et al., 2012; Ahmad et al., 2013).

Desulfurization gypsum provides a sources of $\mathrm{Ca}^{2+}$ to replace exchangeable $\mathrm{Na}^{+}$, thereby improving the physical condition of the soil and increasing water infiltration (Oster, 1982; Wang et al., 2013; Wang \& Yang, 2018). Manure application improves soil structure and alleviates soil sodicity (Yu et al., 2010). Sanding to saline-sodic soils changes soil compactness and reduces salt content (Wang et al., 2010). These amendments showed various improvements of saline-sodic soil properties in practice. 
Crops respond to salinity and sodicity in two phases: (1) a continuous osmotic phase that occurs when the potential energy of the saline-sodic soil solution is lowered by its osmotic pressure, thus inhibiting the water uptake of plants; and (2) a slower ionic phase due to ion toxicity or ion imbalance as plants accumulate salt ions over a period of time (Munns \& Tester, 2008). Most amendment studies focused on soil physiochemical properties (Chi et al., 2012; Zhao et al., 2018) rather than on the osmotic potential in the soil solution and the selective absorption of ions by plants, although they have important effects on crop biomass (Wang et al., 2009).

Rice showed moderate sensitivity to salinity and sodicity (Maas \& Hoffman, 1977). Kelly \& Rengasamy (2006) showed that osmotic stress is one of the major factors in reducing crop yield. The decreasing the osmotic potential of the soil solution was inhibitory to the water uptake of plant roots (Duarte \& De Souza, 2016). The survival of rice plants under saline-sodic conditions is correlated with $\mathrm{Na}^{+}$and $\mathrm{K}^{+}$ accumulations in plant tissues (Song \& Fujiyama, 1996). Yamanouchi et al. (1987) found that $\mathrm{Na}^{+}$ concentrations in shoots are inversely correlated with the relative plant growth and yield. The susceptibility of rice plants to salinity and sodicity stress is due to the limited ability to restrict $\mathrm{Na}^{+}$transportation to shoots (Matsushita \& Matoh, 1991). This $\mathrm{Na}^{+}$restricts $\mathrm{K}^{+}$uptake and $\mathrm{K}^{+}$is an essential macronutrient for the growth of plants and cannot be substituted by $\mathrm{Na}^{+}$(Bhandal \& Malik, 1988). The ability of plants to keep a high cytoplasmic $\mathrm{K}^{+} / \mathrm{Na}^{+}$ratio is one of the most important mechanisms of salt tolerance (Maathuis \& Amtmann, 1999).

In this study, we measured the osmotic potential in the soil solution, characterized $\mathrm{K}^{+}$and $\mathrm{Na}^{+}$ absorption of rice, $\mathrm{K}^{+}$and $\mathrm{Na}^{+}$concentrations in shoots and roots, selective absorption/transport for $\mathrm{K}^{+}$over $\mathrm{Na}^{+}$, distribution of $\mathrm{K}^{+}, \mathrm{Na}^{+}$in rice organs, and yield of rice under various soil treatments, including chemical treatment (desulfurization gypsum, DG), physical treatment (sandy soil, SS) and organic treatment (farmyard manure, FM) as well as mixed treatment (M) in saline-sodic soil for planting rice in field. We hypothesized that (1) amendments would increase the osmotic potential in soil solutions; (2) amendments would alter the ion selective absorption and selective transport in saline-sodic soils and (3) the grain yield of rice would be highest by $\mathrm{M}$ application according to the synergy among treatments when they applied together in the Songnen Plain, northeast China. 
86

87

\section{Materials \& Methods}

\section{Location description}

The study was conducted from 2009 to 2017 at Da'an Sodic Land Experiment Station $\left(45^{\circ} 35^{\prime} 58^{\prime \prime}\right.$ $45^{\circ} 36^{\prime} 28^{\prime \prime} \mathrm{N}, 123^{\circ} 50^{\prime} 27^{\prime \prime}-123^{\circ} 51^{\prime} 31^{\prime \prime} \mathrm{E}, 132.1$ m.a.s.l.(above sea level)), operated by the Chinese Academy of Sciences. The climate of this region is semi-humid to semi-arid continental monsoon. The annual mean air temperature is $4.7^{\circ} \mathrm{C}$, and the mean annual precipitation of this area is approximately $400-500 \mathrm{~mm}$, and $80 \%$ or more of the precipitation occurs between May and September.

The soil at this study site is classified as clay loam with montmorillonite as a dominant mineral. The soil prior to the start of the experiment represents a typically severe saline-sodic soil with $\mathrm{pH}\left(1: 5 \mathrm{H}_{2} \mathrm{O}\right)$ of 10.47, electrical conductivity (EC) $\left(1: 5 \mathrm{H}_{2} \mathrm{O}\right)$ of $2.36 \mathrm{mS} \mathrm{cm}-1$, soil organic C (SOC) of $2.80 \mathrm{~g} \mathrm{~kg}^{-1}$ and exchangeable sodium percentage at $79.7 \%$ in the top $20-\mathrm{cm}$ soil layer, which is considered to be the effective rooting zone. The main soluble cation was $\mathrm{Na}^{+}$, while the anions were $\mathrm{HCO}_{3}{ }^{-}$and $\mathrm{CO}_{3}{ }^{2-}$. $\mathrm{Based}$ on the World Reference Base for Soil Resources (IUSS Working Group WRB, 2007), the main soil type was classified as solonetz.

\section{Field design and treatments}

The experiment was arranged in a random block design with three replicates of $20 \mathrm{~m}^{2}$ for each plot. There were five treatments: (1) CK, without amendment application; (2) DG, amended with desulfurization gypsum (containing 93\% $\mathrm{CaSO}_{4} \cdot 2 \mathrm{H}_{2} \mathrm{O}$ ) at $3 \mathrm{~kg} \mathrm{~m}^{-2}$; (3) $\mathrm{SS}$, amended with sandy soil at $6 \mathrm{~kg} \mathrm{~m}^{-2}$; (4) FM, amended with $6 \mathrm{~kg} \mathrm{~m}^{-2}$ farmyard manure (5) M, amended with the mixture of desulfurization gypsum, sandy soil and farmyard manure, the amounts of which are equal to those in the DG, SS and FM treatments. Some essential properties of the amendments used in the present study are presented in Table 1 (Luo et al., 2018). Plastic cloth buried between plots to a depth of $1 \mathrm{~m}$ soil separated plots to prevent disturbance of lateral movement of amendments, water and salt.

The soil amendments were only applied once before the start of this experiment in the late autumn, 2009. The soil amendments were mixed with the $0-20 \mathrm{~cm}$ soil layer by rotary cultivator and then irrigation was carried out after $24 \mathrm{~h}$. The CK was also treated by the same method except for the amendment. Agronomic and fertilizer management practices for rice cultivation were the same in all plots and were in 
113 accordance with the prevalent system of agriculture in this area. Chemical fertilizers were broadcast over

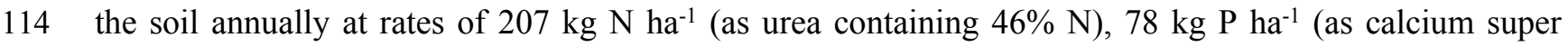

115 phosphate containing $12 \% \mathrm{P}_{2} \mathrm{O}_{5}$ ) and $60 \mathrm{~kg} \mathrm{~K} \mathrm{ha}^{-1}$ (as potassium sulfate containing $45 \% \mathrm{~K}_{2} \mathrm{O}$ ). The soil was

116 then plowed to mix the fertilizers into the subsoil.

117 The local rice cultivar (G19) was planted after wet plowing and sinking between May 20 to the end of

118 May every year for the experiment. Rice seed was sown on normal soil in a greenhouse in early April for

119 nursing, and the 40-day seedlings were transplanted into the plots with a fixed planting spacing of $30 \times 16.7$

$120 \mathrm{~cm}$. Planting space of $30 \times 16.7 \mathrm{~cm}$ is a common practice to avoid lodging, and cultivation of $3-5$ seedlings

121 per hill is recommended in saline-sodic soil in the Songnen plain (Wang et al, 2010). The depth of 3-7 cm

122 standing water was maintained in the paddy through flood irrigation and runoff drainage during the growth

123 stages of rice. The soils were all drained in the middle of September for harvest.

\section{Measurements}

$125 \mathrm{~K}^{+}$and $\mathrm{Na}^{+}$concentrations in rice plant were measured by sampling three hills excluding the border

126

127

128

129

130

131

132

133

134

135

136

137

138

139

hills from each plot on 20 days before harvesting in 2017. The selected rice hills were observed to be representative of the plot. The rice plants were separated into roots, leaves, sheaths and panicles. The roots were thoroughly washed with water to remove the soil particles. Clean roots were used for estimating $\mathrm{Na}^{+}$ and $\mathrm{K}^{+}$concentrations. Plant samples were dried for $48 \mathrm{~h}$ at $80^{\circ} \mathrm{C}$ in an air-forced oven. Dried materials were finely grounded using a ball mill. They were then digested using an acid mixture [sulphuric acid: perchloric acid $\left.\left(\mathrm{H}_{2} \mathrm{SO}_{4}: \mathrm{HClO}_{4}=4: 1\right)\right]$ (Mori et al., 2011). $\mathrm{K}^{+}$and $\mathrm{Na}^{+}$concentrations were determined using an atomic absorption spectrometer (GGX-900). $\mathrm{K}^{+}$and $\mathrm{Na}^{+}$concentrations in the shoot were calculated from $\mathrm{K}^{+}$and $\mathrm{Na}^{+}$concentrations and dry weights of grains, leaves and sheaths, $\mathrm{K}^{+}$and $\mathrm{Na}^{+}$concentrations in the whole plant were calculated from $\mathrm{K}^{+}$and $\mathrm{Na}^{+}$concentrations and dry weights of grains, leaves, sheaths and roots.

At harvest in October, the following growth and yield data were determined in 2010, 2012, 2015 and 2017: plant height, panicle length, number of grains per panicle, 1000-grain weight and grain yield (Zeng et al., 2000).

To analyze the soil properties as affected by different amendments, soil sampling was performed after 
140 harvest of the rice in the November, 2017. All soil samples, obtained from each plot at six depths of 0-10 $141 \mathrm{~cm}, 10-20 \mathrm{~cm}, 20-40 \mathrm{~cm}, 40-60 \mathrm{~cm}, 60-80 \mathrm{~cm}$ and 80-100 cm, . were dried at $105^{\circ} \mathrm{C}$ for $24 \mathrm{~h}$ and passed

142 through a 2-mm diameter sieve. Soil samples were analyzed for electric conductivity (EC in dS m $\left.{ }^{-1}\right)$, soluble $143 \mathrm{~K}^{+}, \mathrm{Na}^{+}$and $\mathrm{Ca}^{2+}$ using 1: 5 soil to water extracts as described by Sumner (1993).

144 The EC of 1: 5 soil to water extracts $\left(\mathrm{EC}_{1: 5}\right)$ was determined by DDS-307 conductivity meter (Shanghai 145 Precision Scientific Instrument Co., Ltd., China), the concentrations in $\mathrm{mmol}_{\mathrm{c}} / \mathrm{L}$ of $\mathrm{K}^{+}, \mathrm{Na}^{+}$were determined using flame photometry (FP-6410) and the concentration of $\mathrm{Ca}^{2+}$ was measured by EDTA titration (Jackson, 1956).

The osmotic potential can serve as a good index for evaluating plant response to saline-sodic stress (De Souza et al., 2012). In this experiment, we regard the 1: 5 soil to water extracts as soil solution, and the osmotic potential in the soil solution (OPss) was calculated as follows:

$\mathrm{OP}_{\mathrm{ss}}=(-0.36) \times 10 \mathrm{EC}($ Bohn et al., 2002)

152

153

\section{SA and ST Calculation}

Selective absorption of $\mathrm{K}^{+}$over $\mathrm{Na}^{+}(\mathrm{SA})$ represents the net capacity of a plant to absorb $\mathrm{K}^{+}$relative to $\mathrm{Na}^{+}$from the shallow soil $(0-40 \mathrm{~cm})$; Selective transport of $\mathrm{K}^{+}$over $\mathrm{Na}^{+}(\mathrm{ST})$ reflects the net capacity of a plant to favour transport of $\mathrm{K}^{+}$over $\mathrm{Na}^{+}$from the root to shoot (Wang et al., 2004). In this study, SA and ST values were calculated according to the following formula (Wang et al., 2002; Wang et al., 2004) using data obtained from the experiments described earlier:

$\mathrm{SA}=(\mathrm{K} / \mathrm{Na}$ in root dry weight $) /($ soil $\mathrm{K} / \mathrm{Na}$ at $0-40 \mathrm{~cm}$ depth $)$

$\mathrm{ST}=(\mathrm{K} / \mathrm{Na}$ in shoot dry weight $) /(\mathrm{K} / \mathrm{Na}$ in root dry weight $)$

\section{Statistical analysis}

Statistical analysis was performed by using the statistical software SPSS 20.0 (New York, USA). We used a randomized block design with three replicates, treated block as a random effect and allowing treatment to enter the model as a fixed effect. One-way analysis of variance (ANOVA) was used for comparing the differences in the means among treatments within each plot. On the basis of the ANOVA results, Duncan's multiple range test (DMRT) was used to determine differences among the amendment treatments. A probability value of $P<0.05$ was used as the criterion for statistical significance. 


\section{Results}

\section{Effect of amendments application on osmotic potential in soil solution}

The osmotic potential in the soil solution $\left(\mathrm{OP}_{\mathrm{ss}}\right)$ was increased by amendments application compared to the control. The amplitude of variation of $\mathrm{OP}_{\mathrm{ss}}$ was from -4.39 bars in the $80-100 \mathrm{~cm}$ soil layer under $\mathrm{CK}$ treatment to -1.04 bars in the $10-20 \mathrm{~cm}$ soil layer under $\mathrm{M}$ treatment. In the $0-40 \mathrm{~cm}$ soil layer, amendments application generally increased the $\mathrm{OP}_{\mathrm{ss}}$ values in the following order: $\mathrm{M}>\mathrm{DG}>\mathrm{SS}>\mathrm{FM}>\mathrm{CK}$ (Figure 1). In the $0-10 \mathrm{~cm}$ soil layer, the M, DG, SS and FM treatment increased the $\mathrm{OP}_{\mathrm{ss}}$ by $53.8 \%, 40.1 \%, 29.1 \%$ and $12.2 \%$ compared to the $\mathrm{CK}$ treatment, respectively. In the same soil layer, the highest $\mathrm{OP}_{\mathrm{ss}}$ was observed for M, which means that the ability to reduce the salt concentration of soil solution is strongest, followed by DG.

\section{Effect of amendments application on $\mathrm{Na}^{+}$and $\mathrm{K}^{+}$concentrations in rice shoots and roots}

$\mathrm{The}^{\mathrm{Na}} \mathrm{a}^{+}$concentration in shoots of rice plants varied with different amendments applied in the salinesodic soil (Figure 2A). Rice shoots of plants in $\mathrm{M}$ treatment showed the lowest $\mathrm{Na}^{+}$concentration of 0.91 $\mathrm{mg} / \mathrm{g}$ dry weight, and the $\mathrm{Na}^{+}$concentrations in FM, CK, SS and DG treatments were $4.4 \%, 7.7 \%, 8.8 \%$ and $11.0 \%$ higher than that in $\mathrm{M}$ treatment, respectively. The difference in $\mathrm{Na}^{+}$concentration between DG and $\mathrm{M}$ treatments was significant. The mean root $\mathrm{Na}^{+}$concentration was highest in the $\mathrm{CK}$ treatment, and $0.8 \%, 7.1 \%, 9.2 \%$ and $15.1 \%$ lower in $\mathrm{M}, \mathrm{SS}, \mathrm{FM}$ and DG treatments, respectively. However, the differences on $\mathrm{Na}^{+}$concentration in rice root among amendment treatments and $\mathrm{CK}$ were non-significant (Figure 2B). Amendments application significantly enhanced $\mathrm{K}^{+}$concentration in rice shoots compared to the control treatment, with the highest $\mathrm{K}^{+}$concentration found for DG (Figure $2 \mathrm{C}$ ). The $\mathrm{K}^{+}$concentration in rice roots with $\mathrm{M}, \mathrm{SS}, \mathrm{FM}$ treatments were lower than that with the control treatment. The lowest $\mathrm{K}^{+}$ concentration was observed for FM, which was 16.8\% lower than that of CK (Figure 2D).

\section{Selective absorption and transport of $\mathrm{K}^{+}$over $\mathrm{Na}^{+}$in rice plant}

Compared to the CK treatment, the M treatment significantly decreased the SA value of the rice by $74.8 \%$ (Figure $3 \mathrm{~A}$ ). However, the $\mathrm{M}$ treatment significantly increased the ST value of the rice compared to the CK treatment, which was 1.5 times more than the ST value of the CK treatment (Figure 3B). 
Amendment application hindered the uptake of $\mathrm{K}^{+}$over $\mathrm{Na}^{+}$from soil to root (SA) compared with CK (Figure 3A), which is probably a consequence of rice physiological adjustment. Amendment application enhanced the uptake of $\mathrm{K}^{+}$over $\mathrm{Na}^{+}$from root to shoot (ST) compared with CK (Figure 3B). This was attributed to strong selective transport of $\mathrm{K}^{+}$over $\mathrm{Na}^{+}$under amendment application.

The mean $\mathrm{Na}^{+}$concentration in the soil extracts decreased from a maximum $\left(6.68 \mathrm{mmol}_{\mathrm{c}} / \mathrm{L}\right)$ in the $\mathrm{CK}$ treatment to $3.16,4.35,5.11$ and $6.60 \mathrm{mmol}_{\mathrm{c}} / \mathrm{L}$ with $\mathrm{M}, \mathrm{DG}, \mathrm{SS}$ and FM treatments, respectively. The differences among $\mathrm{M}$ and $\mathrm{CK}$ were significant (Figure 4A). Amendment application slightly enhanced the $\mathrm{K}^{+}$concentration in the soil extracts compared to $\mathrm{CK}$ (Figure 4B). The $\mathrm{Ca}^{2+}$ concentration in the soil extracts were higher for treatments with amendments than the one without, and differences among the 4 different amendments were not significant (Figure 4C).

\section{Characteristics of distribution of $\mathrm{Na}^{+}$and $\mathrm{K}^{+}$in rice with different amendments application}

There were little differences in $\mathrm{Na}^{+}$concentration in the whole rice plants among different treatments in the saline-sodic soils in this experiment (Figure $5 \mathrm{~A}$ ). $\mathrm{K}^{+}$concentration in the whole plant was significantly enhanced after amendment application, but the differences between the 4 treatments with amendments were non-significant (Figure 5B). $\mathrm{Na}^{+}$absorbed by the whole plant was almost the same with and without amendments, which was different from the observations on rice organs (Figure 5A and Table 2). The $\mathrm{Na}^{+}$concentrations in rice roots and grains both decreased when applying amendments in the salinesodic soils; which were contrary to the rise of $\mathrm{K}^{+}$concentrations in sheaths and leaves (Table 2). Compared to the control treatment, DG, SS, FM and $\mathrm{M}$ treatments increased the $\mathrm{K}^{+}$concentrations in rice sheaths by $57.2 \%, 54.9 \%, 44.1 \%$ and $25.5 \%$, respectively.

For the distribution of ions in rice organs, there was a higher proportion of the total $\mathrm{K}^{+}$in leaves. More $\mathrm{Na}^{+}$was found in roots. The order of accumulation of $\mathrm{Na}^{+}$in various organs was roots $>$ leaves $>$ sheaths $>$ grains (Table 2 ). The order is imposed by the fact that the root system retains more $\mathrm{Na}^{+}$and prevents $\mathrm{Na}^{+}$from being transported to the aboveground organs in saline-sodic soils, resulting in higher $\mathrm{K}^{+}$proportion in leaves, sheaths and grains. This was also illustrated as being beneficial to normal metabolic activity (Borsani, 2001; Ahmad \& Jabeen, 2005).

Peer] reviewing PDF | (2019:06:38932:4:0:NEW 16 Jan 2020) 
221

222

223

224

225

226

227

228

229

230

231

232

233

234

235

236

237

238

239

240

241

242

243

244

245

246

247

\section{Relationship between $\mathrm{OP}_{\mathrm{ss}}$, selective absorption and yield of rice}

The grain yield of the four years of 2010, 2012, 2015 and 2017 were taken as representative of the trend of rice yield from 2009 to 2017 (Figure 6). In terms of grain yield, the M was the best treatment, next is the DG treatment. The grain yield of rice with amendments application were significantly higher than without amendments application except in 2015.

Amendment treatments significantly enhanced the grain yield of rice compared to the control in 2017 (Table 3). The differences, however, among different amendments were not significant at $P<0.05$. Soil amendment application generally increased the 1000-grain weight in the following order: $\mathrm{FM}>\mathrm{M}>\mathrm{DG}>\mathrm{SS}>\mathrm{CK}$ (Table 3). Additionally, the FM and M treatments significantly increased the 1000grain weight to 1.16 and 1.13 times more than the CK treatment, respectively (Table 3 ). Compared to the CK treatment, the SS treatment considerably enhanced the number of grains per panicle (Table 3). There was no significant difference on rice height and panicle length between various treatments (Table 3).

Significant positive correlations were found between $\mathrm{OP}_{\mathrm{ss}}$ in the $0-20 \mathrm{~cm}$ soil layer and the 1000 -grain weight $\left(\mathrm{R}^{2}=0.992, P<0.001\right.$, Table 4). Significant negative correlations were found between SA and rice grain yield $\left(\mathrm{R}^{2}=0.925, P<0.05\right.$, Table 4$)$ and between $\mathrm{SA}$ and 1000 -grain weight of rice $\left(\mathrm{R}^{2}=0.884, P=0.047\right.$, Table 4). There was no significant correlation between either SA or ST and other growth parameters and yield of rice (Table 4).

\section{Discussion}

\section{Characteristics of $\mathrm{Na}^{+}$and $\mathrm{K}^{+}$absorption in rice}

Compared with the $\mathrm{CK}$ treatment, the selective absorption of $\mathrm{K}^{+}$over $\mathrm{Na}^{+}(\mathrm{SA})$ decreased significantly with the $\mathrm{M}$ application in this study. When the $\mathrm{M}$ applied, osmotic stress and $\mathrm{Na}^{+}$toxicity were significantly decreased leading to better plant growth in saline-sodic soils (Swarup, 1982; Yuncai et al., 2005; Luo et al., 2018; Shi et al., 2019). Similar to our results, previous studies have shown that plants accumulate excessive $\mathrm{Na}^{+}$in their shoots under stress caused by high salinity-sodicity (Roy \& Mishra, 2014), and $\mathrm{Na}^{+}$ concentration in shoots increased significantly with a surge in soil salinity-sodicity (Syed \& Abdur, 2017).

Adding amendments reduces the salinity-sodicity stress of plants growing in the amended soil (Chaganti \& Crohn, 2015). Therefore, the rice planted in the CK plot was under a higher external salinity- 
248

249

250

251

252

253

254

255

256

257

258

259

260

261

262

263

264

265

266

267

268

269

270

271

272

273

274

sodicity stress. As a result, the SA value of rice plants with CK was higher than those with amendments application and maintained a high cytosolic $\mathrm{K}^{+} / \mathrm{Na}^{+}$ratio. This is thought to be one of the most important mechanisms of salt tolerance exhibited by plants (Gorham, 1990; Dubcovsky et al., 1996; Munns \& James, 2008; Munns et al., 2010).

\section{Effects of $\mathrm{Ca}^{2+}$ on SA and ST values}

The competition between $\mathrm{K}^{+}$and $\mathrm{Na}^{+}$to entry into plants can result in significant adverse effects on plants' growth, where concentrations of $\mathrm{Na}^{+}$often exceed those of $\mathrm{K}^{+}$(Tester \& Davenport, 2003). Therefore, the maintenance of a high $\mathrm{K}^{+} / \mathrm{Na}^{+}$ratio in plants is essential (Maathuis \& Amtmann, 1999). Amendments of $\mathrm{Ca}^{2+}$ promoted $\mathrm{K}^{+}$over $\mathrm{Na}^{+}$absorption, resulting in the enhancement of selective absorption of $\mathrm{K}^{+}$over $\mathrm{Na}^{+}$(Alama et al., 2002). $\mathrm{Ca}^{2+}$ can replace $\mathrm{Na}^{+}$in plants, which restores cell wall stability and plasma membrane integrity (Zhang et al., 2010; Wu \& Wang, 2012). Although alleviation of $\mathrm{Na}^{+}$toxicity by supplemental $\mathrm{Ca}^{2+}$ was confirmed, the responses varied with different plant species. Under similar saline-sodic conditions, amendments of $\mathrm{Ca}^{2+}$ were found to obviously increase $\mathrm{K}^{+} / \mathrm{Na}^{+}$selectivity of both roots and shoots (SA and ST values) in Medicago sativa (Al-Khateeb, 2006) and Cornus sericea (Renault \& Affifi, 2009). This is in contrast with Wang et al. (2007), who reported that amendments of $\mathrm{Ca}^{2+}$ had no influence on SA and ST values of Suaeda maritima. In addition, the responses of $\mathrm{Na}^{+}$to $\mathrm{Ca}^{2+}$ also varied with osmotic potential in soil solution in the same plant species. In rice, $\mathrm{Ca}^{2+}$ did not have significant effects on selective absorption and selective transport of $\mathrm{K}^{+}$over $\mathrm{Na}^{+}$of plants when subjected to low osmotic potential in soil solution (Yeo \& Flowers, 2010). This is consistent with the results obtained in the present study: there were not significant differences among CK, DG, SS and FM treatment on SA and ST values (Figure 3). In contrast, $\mathrm{M}$ application significantly decreased roots $\mathrm{Na}^{+}$absorption and increased shoots $\mathrm{K}^{+}$accumulation in rice. It is proposed that the presence of $\mathrm{Ca}^{2+}$ could enhance $\mathrm{K}^{+} / \mathrm{Na}^{+}$selectivity and regulate ion homeostasis in rice under low saline-sidicity condition.

In rice, a minority of the ions reaching the plant shoots are the consequence of leakage along the transpirational bypass flow to the xylem and $\mathrm{Ca}^{2+}$ application can reduce the bypass flow of rice (Faiyue et al., 2010; Anil et al., 2005). This reduction in the bypass flow is positively related with the concomitant reduction in the shoot $\mathrm{Na}^{+}$uptake (Anil et al. 2005). In addition, a majority of the ions reaching the shoots 
275

276

277

278

279

280

281

282

283

of rice should be transported via the symplast pathway. Therefore, $\mathrm{Ca}^{2+}$ plays important role in regulating apoplast and symplast pathways involved in $\mathrm{Na}^{+}$transport.

\section{Yield of rice}

Transient salinity affects the plants' absorption of available water, which results in a reduction in plant yield (Rengasamy, 2010a, 2010b). However, application of amendments to saline-sodic soils can alleviate the salinity-sodicity stress on plants (Irshad et al., 2002). Amendments application in our study enhanced the $\mathrm{OP}_{\mathrm{ss}}$ values, and then decreased osmotic pressure of the soil solution. This ultimately increased the plant growth and yield of rice in the saline-sodic soils. Applying a small amount of calcium thus was shown to enhance the plants' salt tolerance (Cramer, 1992).

DG, SS and FM application are known to improve the root environment and increase rice yield (Abrishamkesh et al., 2015). In this study, we found that the mixture of DG, SS and FM application significantly reduced the absorption of $\mathrm{Na}^{+}$in rice shoots and led to the highest rice grain yields, which may be due to the synergistic effect of these three amendments. However, the contribution of each amendment to the rice yield needs to be quantified in future studies.

\section{Conclusions}

In this field experiment, the amendments application significantly increased the yield of rice. In particularly, the $\mathrm{M}$ treatment was the best among the tested amendment treatments, with the highest rice grain yield in the saline-sodic soils, although the differences between amendment treatments were not significant. Relative to the CK treatment, the FM and M treatments significantly enhanced the 1000-grain weight and the SS treatment significantly improved the number of grains per panicle. All treatments increased the $\mathrm{OP}_{\mathrm{ss}}$ significantly, thus relieving the inhibition of water uptake by plants. In addition, a positive effect of amendments application on reducing $\mathrm{Na}^{+}$accumulation and increasing the uptake of $\mathrm{K}^{+}$ of rice shoot was observed. Amendments application increased ST values and decreased SA values. Moreover, there existed an ion regionalization distribution in rice plant; there was a higher $\mathrm{K}^{+}$proportion in leaves and a higher $\mathrm{Na}^{+}$proportion in roots. Collectively, the mixture of desulfurization gypsum, sandy soil and farmyard manure provided excellent results for increasing the yield of rice in the saline-sodic soils in the Songnen Plain, northeast China. 


\section{Acknowledgements}

303 We thank Da' an Sodic Land Experiment Station of China for providing experimental plot.

\section{References}

305 Abrishamkesh S, Gorji M, Asadi H. 2015. Effects of rice husk biochar application on the properties of alkaline soil

Ahmad R, Jabeen R. 2005. Foliar spray of mineral elements antagonistic to sodium a technique to induce salt tolerance in plants growing under saline conditions. Pakistan Journal of Botany 37: 913-920.

Ahmad S, Ghafoor A, Akhtar ME, Khan MZ. 2013. Ionic displacement and reclamation of saline-sodic soils using chemical amendments and crop rotation. Land Degradation and Development 24: 170-178.

Alama S, Huqb SMI, Kawai S, Islam A. 2002. Effects of applying calcium salts to coastal saline soils on growth and mineral nutrition of rice varieties. Journal of Plant Nutrition 25: 561-575.

Al-khateeb SA. 2006. Effect of calcium/sodium ratio on growth and ion relations of alfalfa (Medicago sativa L.) seedling s growth under saline condition. Journal of Agronomy 5: 175-181.

Anil VS, Kirishnamurthy P, Kuruvilla S, Suchartha K, Thomas G, Mathew MK. 2005. Regulation of the uptake and distribution of $\mathrm{Na}^{+}$in shoots of rice (Oryza sativa) variety Pokkali: role of $\mathrm{Ca}^{2+}$ in salt tolerance response. Physiologia Plantarum 124: 451-464.

Bhandal IS, Malik CP. 1988. Potassium estimation, uptake, andits role in the physiology and metabolism of flowering plants. International Review of Cytology 110: 205-254.

Bohn HL, Myer RA, O'Connor GA. 2002. Soil chemistry. John Wiley \& Sons.

Borsani O. 2001. Identification of two loci in tomato reveals distinct mechanisms for salt tolerance. The Plant Cell Online 13: 873-888.

Chaganti VN, Crohn DM. 2015. Evaluating the relative contribution of physiochemical and biological factors in ameliorating a saline-sodic soil amended with composts and biochar and leached with reclaimed water. Geoderma 259-260: 45-55.

Chi CM, Zhao CW, Sun XJ, Wang ZC. 2012. Reclamation of saline-sodic soil properties and improvement of rice (Oriza sativa L.) growth and yield using desulfurized gypsum in the west of Songnen Plain, northeast China. Geoderma 187: 24-30. 
329

330

331

332

333

334

335

336

337

338

339

340

341

342

343

344

345

346

347

348

349

350

351

352

353

354

355

Cramer GR. 1992. Kinetics of maize leaf elongation. II. Responses of a Na-excluding cultivar and a Na-including cultivar to varying Na/Ca salinities. Journal of Experimental Botany 43: 857-864.

De Souza ER, Freire MBGDS, da Cunha KPV, do Nascimento CWA, Ruiz HA, Lins CMTSouza ERD, Freire MBGDS, Karina Patrícia Vieira da Cunha. 2012. Biomass, anatomical changes and osmotic potential in Atriplex nummularia Lindl. cultivated in sodic saline soil under water stress. Environmental and Experimental Botany 82: $20-27$.

Duarte HHF, De Souza ER. 2016. Soil water potentials and Capsicum annuum L. under salinity. Revista Brasileira de Ciência do solo 40: 1-11.

Dubcovsky J, Santa MG, Epatein E, Luo MC, Dvorak J. 1996. Mapping of the $\mathrm{K}^{+} / \mathrm{Na}^{+}$discrimination locusKnal in wheat. Theoretical and Applied Genetics 92: 448-454.

Faiyue B, Vijayalakshmi C, Nawaz S, Nagato Y, Taketa S, Ichii M, Azzawi MJA, Flowers TJ. 2010. Studies on sodium bypass flow in lateral rootless mutants $1 \mathrm{rt1}$ and lrt2, and crown rootless mutant crl1 of rice (Oryza sativa L.). Plant Cell and Environment 33: 687-701.

Gharaibeh MA, Eltaif NI, Shra'Ah SH. 2010. Reclamation of a calcareous saline-sodic soil using phosphoric acid and by-product gypsum. Soil Use and Management 26: 141-148.

Gorham J. 1990. Salt tolerance in the Triticeae: K/Na discrimination in Aegilops species. Journal of Experimental Botany 41: 1095-1101.

Irshad M, Honna T, Eneji AE, Yamamoto S. 2002. Wheat response to nitrogen source under saline conditions. Journal of Plant Nutrition 25: 2603-2612.

Jackson ML. 1956. Soil chemical analysis-advanced course: Published by the author. Madison, Wisconsin: 895.

Kelly J, Rengasamy P. 2006. Diagnosis and management of soil constraints: transient salinity, sodicity and alkalinity. The University of Adelaide and Grain Research and Development Corporation, Australia.

Luo SS, Wang SJ, Lei T, Shi SH, Xu SQ, Yang F, Li XJ, Wang ZC, Tian CJ. 2018. Aggregate-related changes in soil microbial communities under different ameliorant applications in saline-sodic soils. Geoderma 329: 108-117.

Maas EV, Hoffman GJ. 1977. Crop salt tolerance-current assessment. Journal of the irrigation and drainage division 103: $115-134$.

Maathuis FJ, Amtmann A. 1999. $\mathrm{K}^{+}$nutrition and $\mathrm{Na}^{+}$toxicity: the basis of cellular $\mathrm{K}^{+} / \mathrm{Na}^{+}$ratios. Annals of Botany 
356

357

358

359

360

361

362

363

364

365

366

367

368

369

370

371

372

373

374

375

376

377

84: $123-133$.

Matsushita N, Matoh T. 1991. Characterization of $\mathrm{Na}^{+}$exclusion mechanisms of salt-tolerant reed plants in comparison with salt-sensitive rice plants. Physiologia Plantarum 83: 170-176.

Mori S, Suzuki K, Oda R, Higuchi K, Maeda U, Yoshiba M, Tadano T. 2011. Characteristics of Na and K absorption in Suaeda salsa (L.) Pall. Soil Science and Plant Nutrition 57: 377-386.

Munns R, James RA. 2008. Mechanisms of salinity tolerance. Annual Review of Plant Biology 59: 651-681.

Munns R, Tester M. 2008. Mechanism of salinity of salt tolerance. Annual Review of Plant Biology 59: 651-681.

Munns R, Wallace PA, Teakle NL, Colmer TD. 2010. Measuring soluble ion concentrations $\left(\mathrm{Na}^{+}, \mathrm{K}^{+}, \mathrm{Cl}^{-}\right)$in salttreated plants. In plant Stress Tolerance, Methods and Protocols. New York, USA, Human press, Springer Science.

Oster JD. 1982. Gypsum usage in irrigated agriculture: a review. Fertilizer Research 3: 73-89.

Qadir M, Noble A, Schubert S. 2006. Sodicity-induced land degradation and its sustainable management: Problems and prospects. Land Degradation \& Development 17: 661-676.

Qadir M, Schubert S, Badia D, Sharma BR, Qureshi AS, Murtaza G. 2007. Amelioration and nutrient management strategies for sodic and alkali soils. CAB Reviews Perspectives in Agriculture. Veterinary Science Nutrition and Natural Resources 21: 1-13.

Renault S, Affifi M. 2009. Improving $\mathrm{NaCl}$ resistance of red-osier dogwood: role of $\mathrm{CaCl}_{2}$ and $\mathrm{CaSO}_{4}$. Plant and soil 315: 123-133.

Rengasamy P. 2010a. Osmotic and ionic effects of various electrolytes on the growth of wheat. Australian Journal of Soil Research 48: 120-124.

Rengasamy P. 2010b. Soil processes affecting crop production in salt-affected soils. Functional Plant Biology 37: $613-620$.

Roy C, Mishra R. 2014. Impact of $\mathrm{NaCl}$ stress on the physiology of four cultivars of S. lycopersicum. Research in Plant Biology 4: 09-20.

Shi SH, Tian L, Nasir F, Bahadur A, Batool A, Luo SS, Yang F, Wang ZC, Tian CJ. 2019. Response of microbial communities and enzyme activities to amendments in saline-alkaline soils. Applied Soil Ecology 135: 16-24.

Song JQ, Fujiyama H. 1996. Difference in response of rice and tomato subjected to sodium salinization to the addition of calcium. Soil Science and Plant Nutrition 42: 503-510.

Peer] reviewing PDF | (2019:06:38932:4:0:NEW 16 Jan 2020) 
Suarez DL. 2001. Sodic soil reclamation: Modelling and field study. Soil Research 39: 1225-1246.

Sumner ME. 1993. Sodic soils: new perspectives. Australian Journal of Soil Research 31: 683-750.

Swarup A. 1982. Availability of ions, zinc and phosphorus in submerged sodic soil as affected by amendments during the growth period of rice crop. Plant and Soil 66: 37-43.

Syed GA, Abdur R. 2017. The influence of salinity and drought stress on sodium, potassium and proline content of Solanum lycopersicum L. cv. Rio granded. Pakistan Journal of Botany 49: 1-9.

Tester M, Davenport R. 2003. $\mathrm{Na}^{+}$tolerance and $\mathrm{Na}^{+}$transport in higher plants. Annals of Botany 91: 503-527.

Wang CM, Zhang JL, Liu XS, Li Z, Wu GQ, Cai JY. 2009. Puccinellia tenuiflora maintains a low $\mathrm{Na}^{+}$level under salinity by limiting unidirectional $\mathrm{Na}^{+}$influx resulting in a high selectivity for $\mathrm{K}^{+}$over $\mathrm{Na}^{+}$. Plant, Cell and Environment 32: 486-496.

Wang J, Bai Z, Yang P. 2013. Effect of byproducts of flue gas desulfurization on the soluble salts composition and chemical properties of sodic soils. Plos one 8: e71011.

Wang J, Bai Z, Yang P. 2012. Sodic soil properties and sunflower growth as affected by byproducts of flue gas desulfurization. Plos one 7: e52437.

Wang J, Yang P. 2018. Potential flue gas desulfurization gypsum utilization in agriculture: A comprehensive review. Renewable and Sustainable Energy Reviews 82: 1969-1978.

Wang MM, Liang ZW, Wang ZC, Huang LH, Ma HY, Liu M, Gu X. 2010. Effect of sand application and flushing during the sensitive stages on rice biomass allocation and yield in a saline-sodic soil. Journal of Food, Agriculture and Environment 8: 692-697.

Wang MM, Liang ZW, Yang F, Ma HY, Huang LH, Liu M. 2010. Effects of number of seedlings per hill on rice biomass partitioning and yield in a saline-sodic soil. Journal of Food Agriculture and Environment 8: 628-633.

Wang S, Wan C, Wang Y, Chen H, Zhou Z, Fu Y, Sosebee RE. 2004. The characteristics of $\mathrm{Na}^{+}, \mathrm{K}^{+}$and free proline distribution in several drought resistant plants of the Alxa Desert, China. Journal of Arid Environments 56: $525-539$.

Wang S, Zheng W, Ren J, Zhang C. 2002. Selectivity of various types of salt-resistant plants for $\mathrm{K}^{+}$over $\mathrm{Na}^{+}$. Journal of Arid Environment 52: 457-472.

Wang SM, Zhang JL, Flower TJ. 2007. Low-affinity $\mathrm{Na}^{+}$uptake in the halophate Suaeda maritima. Plant 
Physiology 145: 559-571.

411 Wang SM, Zhao GO, Gao YS, Tang ZC, Zhang CL. 2004. Puccinellia tenuiflora exhibits stronger selectivity for $412 \mathrm{~K}^{+}$over $\mathrm{Na}^{+}$than wheat. Journal of Plant Nutrition 27: 1841-1857.

413 Wu GQ, Wang SM. 2012. Calcium regulates $\mathrm{K}^{+} / \mathrm{Na}^{+}$homeostasis in rice (Oryza sativa $\mathrm{L}$.) under saline conditions. $414 \quad$ Plan Soil and Environment 58: 121-127.

Yamanouchi M, Maeda Y, Nagai T. 1987. Relationship between the salt accumulation in the shoots and the degree of salinity tolerance in rice cultivars. Soil Science Plant Nutrition 58: 591-594.

Yang F, An FH, Ma HY, Wang ZC, Zhou X, Liu Z. 2016. Variations on soil salinity and sodicity and its driving factors analysis under microtopography in different hydrological conditions. Water 8: 227.

Yao RJ. 2008. Development and prospect of the research on salt-affected soils in China. Acta Pedologia Sinica 45: 837-845 (in Chinese).

Yeo AR, Flowers TJ. 2010. The Absence of an effect of the $\mathrm{Na} / \mathrm{Ca}$ ratio on sodium chloride uptake by rice (Oryza sativa L.). New Phytologist 99: 81-90.

Yu JB, Wang ZC, Meixner FX, Yang F, Wu HF, Chen XB. 2010. Biogeochemical characterizations and reclamation strategies of saline sodic soil in northeastern China. CLEAN-Soil, Air, Water 38: 1010-1016.

Yuncai H, Schmidhalter U. 2005. Drought and salinity: A comparison of the effects of drought and salinity. Journal of Plant and Nutrition and Soil Science 168: 247-273.

Zeng L, Shannon MC. 2000. Salinity effects on seedling growth and yield components of rice. Crop Science 40: 996.

Zhang JL, Flowers TJ, Wang SM. 2010. Mechanisms of sodium uptake by roots of higher plants. Plant and Soil 326: 45 .

Zhao YG, Wang SJ, Li Y, Liu J, Zhuo YQ, Chen HX, Wang J, Xu LZ., Sun ZT. 2018. Extensive reclamation of saline-sodic soils with flue gas desulfurization gypsum on the Songnen Plain, Northeast China. Geoderma 321: 52-

\section{Tables}

434 Table 1. Properties of the amendments used in the present study.

Table $2 \mathrm{Na}^{+}$and $\mathrm{K}^{+}$concentrations and $\mathrm{K}^{+} / \mathrm{Na}^{+}$ratios in different organs of rice plant with various 
437

438

439

440

441

442

443

444

445

446

447

448

449

450

451

452

453

454

455

456

457

458

459

460

461

462

463

treatments.

Table 3. Effects of amendments application on growth and yield of rice plant in 2017.

Table 4. Correlation coefficients among OP, SA, ST values and different growth and yield of rice in 2017.

\section{Figures}

Figure 1. Osmotic potential of the 1: 5 soil water extract at various soil profile depths with different amendments application. CK, control, without amendments application; DG, desulfurization gypsum; SS, sandy soil; FM, farmyard manure; M, mixture of desulfurization gypsum, sandy soil and farmyard manure. Bars represent the standard error of the mean of three replications.

Figure $2 . \mathrm{Na}^{+}$and $\mathrm{K}^{+}$concentrations in different parts of rice plants with various treatments. Shoot, the aboveground part of rice; Root, the underground part of rice. $\mathrm{CK}$, control, without amendments application; DG, desulfurization gypsum; SS, sandy soil; FM, farmyard manure; M, mixture of desulfurization gypsum, sandy soil and farmyard manure. Bars represent the standard error of the mean of three replications. Different letters denote means that are significantly different from each other $(P<0.05)$.

Figure 3. Selective absorption (SA) and selective transport (ST) of rice with various treatments. SA values, selective absorption of $\mathrm{K}^{+}$over $\mathrm{Na}^{+}$; ST values, selective transport of $\mathrm{K}^{+}$over $\mathrm{Na}^{+}$. CK, control, without amendments application; DG, desulfurization gypsum; SS, sandy soil; FM, farmyard manure; M, mixture of desulfurization gypsum, sandy soil and farmyard manure. Bars represent the standard error of the mean of three replications. Different letters denote means that are significantly different from each other $(P<0.05)$. 
464 Figure 4. $\mathrm{Na}^{+}, \mathrm{K}^{+}$and $\mathrm{Ca}^{2+}$ concentrations in the 1: 5 soil water extract $(0-40 \mathrm{~cm})$ with various 465 treatments. CK, control, without amendments application; DG, desulfurization gypsum; SS, sandy 466 soil; FM, farmyard manure; M, mixture of desulfurization gypsum, sandy soil and farmyard 467 manure. Bars represent the standard error of the mean of three replications. Different letters denote 468 means that are significantly different from each other $(P<0.05)$.

469

Figure 5. $\mathrm{Na}^{+}$and $\mathrm{K}^{+}$concentrations in the whole rice plant with various treatments. DW, dry weight. CK, control, without amendments application; DG, desulfurization gypsum; SS, sandy soil; FM, farmyard manure; M, mixture of desulfurization gypsum, sandy soil and farmyard manure. Bars represent the standard error of the mean of three replications. Different letters denote means that are significantly different from each other $(P<0.05)$.

Figure 6. The trend of grain yield. CK, control, without amendments application; DG, desulfurization gypsum; SS, sandy soil; FM, farmyard manure; M, mixture of desulfurization gypsum, sandy soil and farmyard manure. Bars represent the standard error of the mean of three replications. 
Figure 1

Osmotic potential of the 1: 5 soil water extract at various soil profile depths with different amendments application.

CK, control, without amendments application; DG, desulfurization gypsum; SS, sandy soil; FM, farmyard manure; $M$, mixture of desulfurization gypsum, sandy soil and farmyard manure. Bars represent the standard error of the mean of three replications.

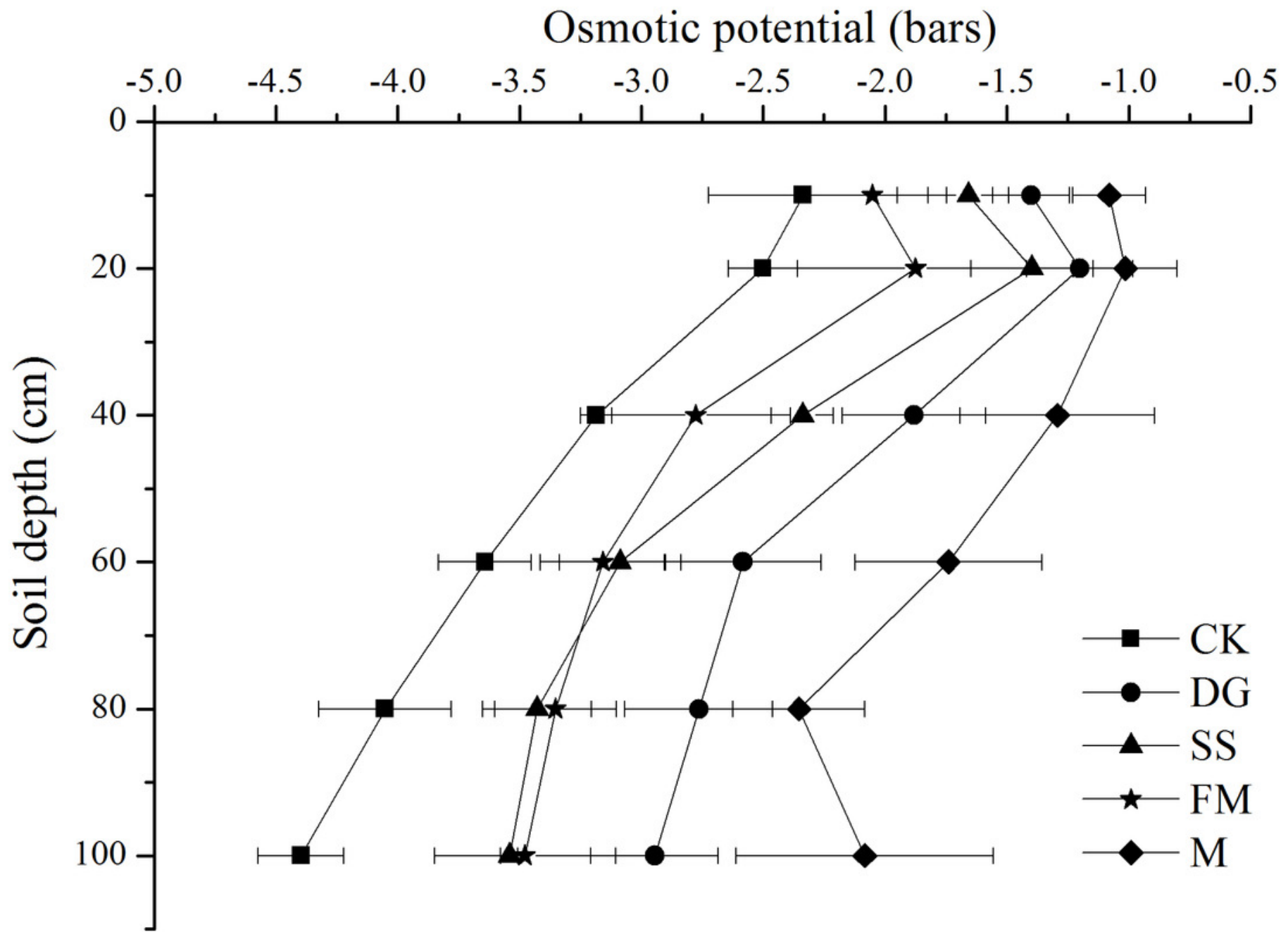


Figure 2

$\mathrm{Na}^{+}$and $\mathrm{K}^{+}$concentrations in different parts of rice plants with various treatments.

Shoot, the aboveground part of rice; Root, the underground part of rice. CK, control, without amendments application; DG, desulfurization gypsum; SS, sandy soil; FM, farmyard manure; $M$, mixture of desulfurization gypsum, sandy soil and farmyard manure. Bars represent the standard error of the mean of three replications. Different letters denote means that are significantly different from each other $(P<0.05)$.

Shoot
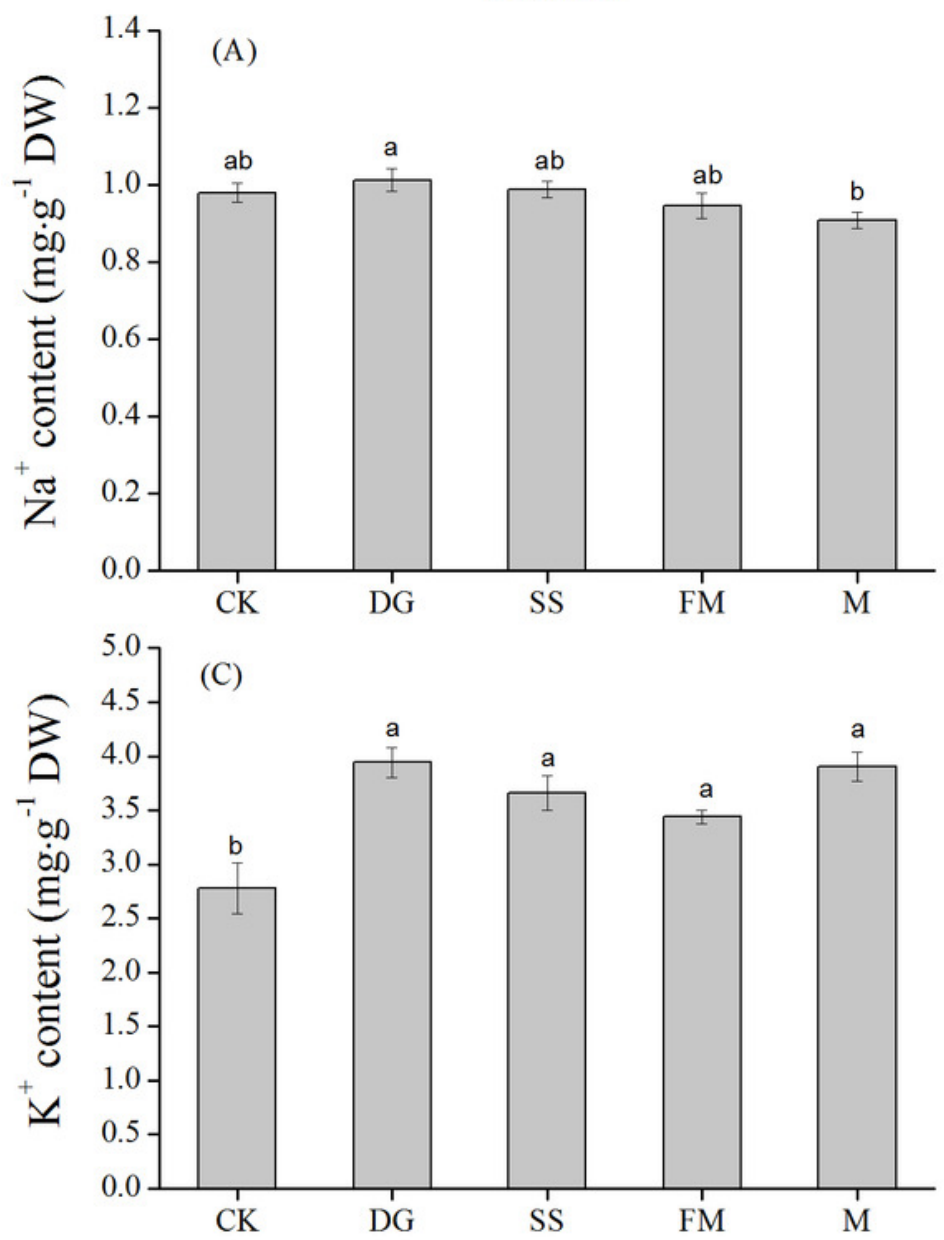
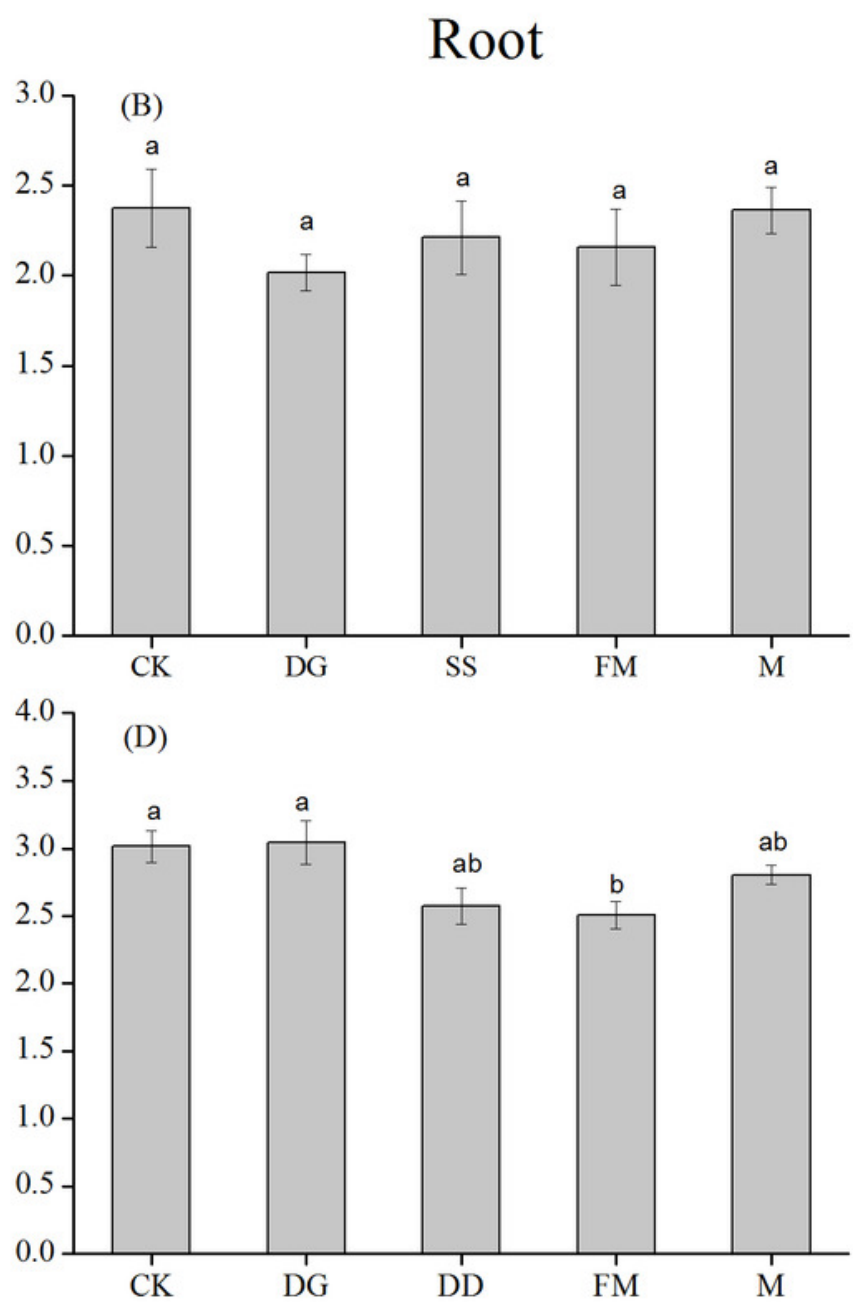

Treatment 
Figure 3

Selective absorption (SA) and selective transport (ST) of rice with various treatments.

SA values, selective absorption of $\mathrm{K}^{+}$over $\mathrm{Na}^{+}$; ST values, selective transport of $\mathrm{K}^{+}$over $\mathrm{Na}^{+}$. CK, control, without amendments application; DG, desulfurization gypsum; SS, sandy soil; FM, farmyard manure; $M$, mixture of desulfurization gypsum, sandy soil and farmyard manure. Bars represent the standard error of the mean of three replications. Different letters denote means that are significantly different from each other $(P<0.05)$.

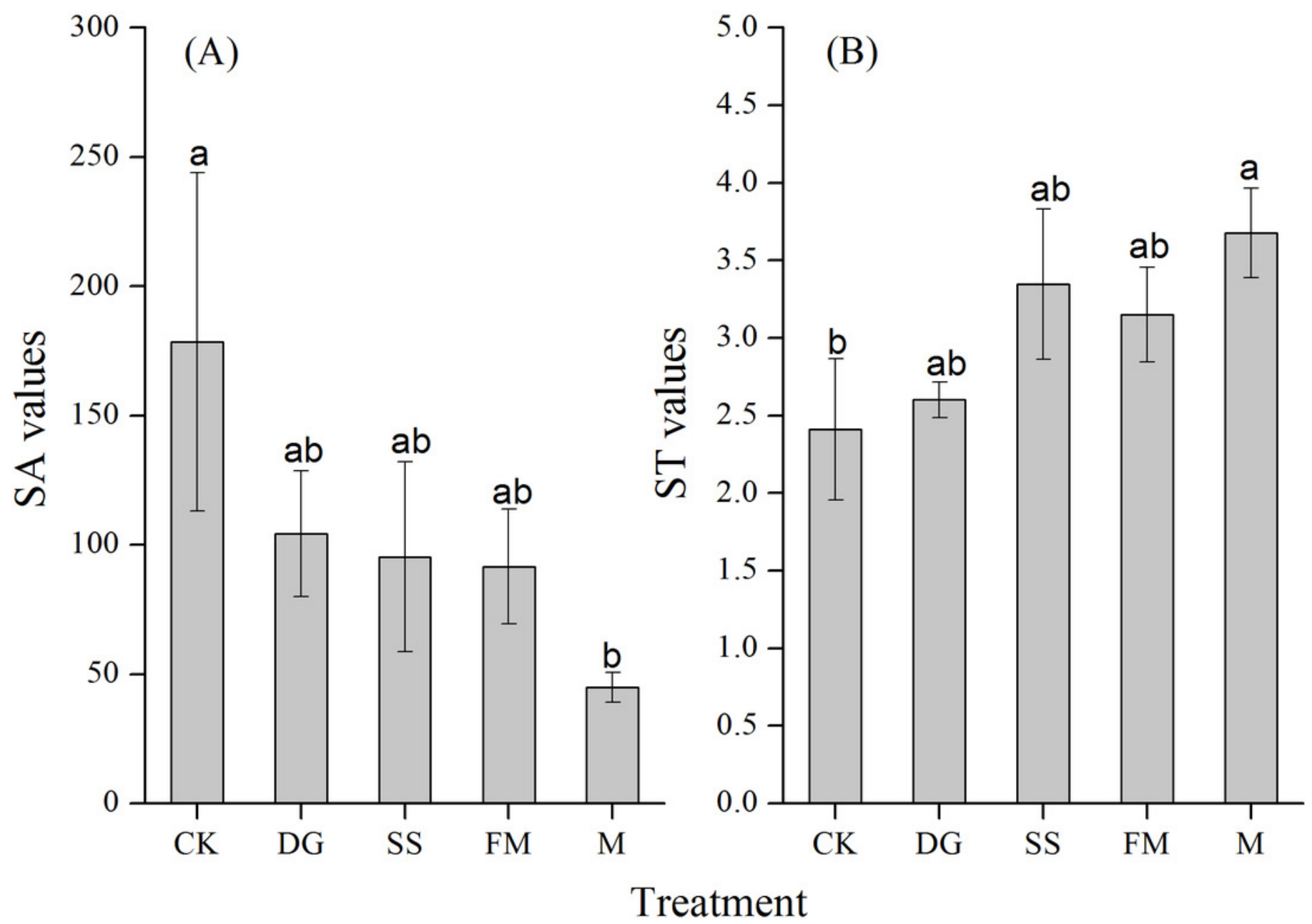


Figure 4

$\mathrm{Na}^{+}, \mathrm{K}^{+}$and $\mathrm{Ca}^{2+}$ concentrations in the $1: 5$ soil water extract $(0-40 \mathrm{~cm})$ with various treatments.

CK, control, without amendments application; DG, desulfurization gypsum; SS, sandy soil; FM, farmyard manure; M, mixture of desulfurization gypsum, sandy soil and farmyard manure. Bars represent the standard error of the mean of three replications. Different letters denote means that are significantly different from each other $(P<0.05)$.
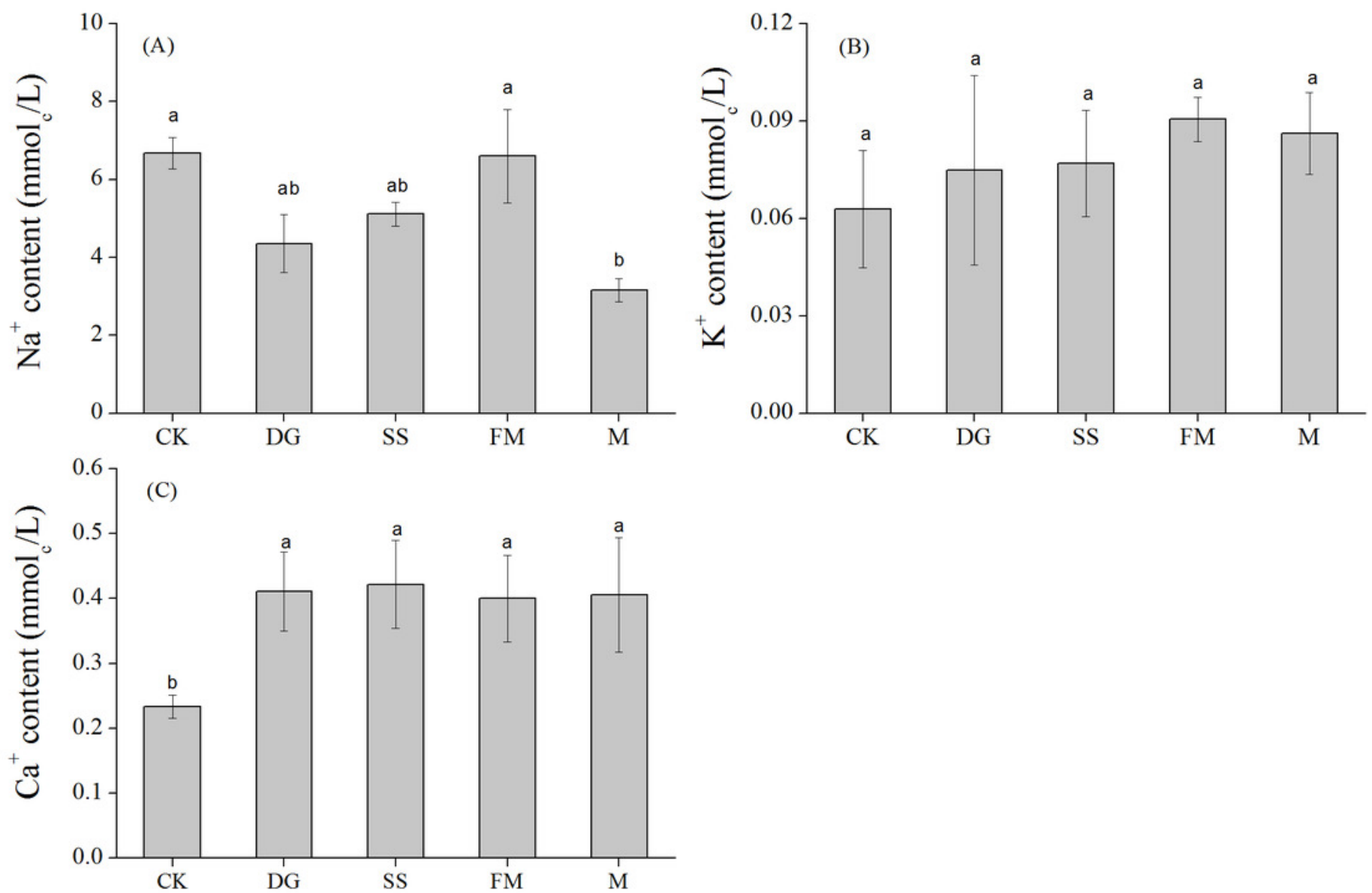

\section{Treatment}


Figure 5

$\mathrm{Na}^{+}$and $\mathrm{K}^{+}$concentrations in the whole rice plant with various treatments.

DW, dry weight. CK, control, without amendments application; DG, desulfurization gypsum;

SS, sandy soil; FM, farmyard manure; M, mixture of desulfurization gypsum, sandy soil and farmyard manure. Bars represent the standard error of the mean of three replications. Different letters denote means that are significantly different from each other $(P<0.05)$.
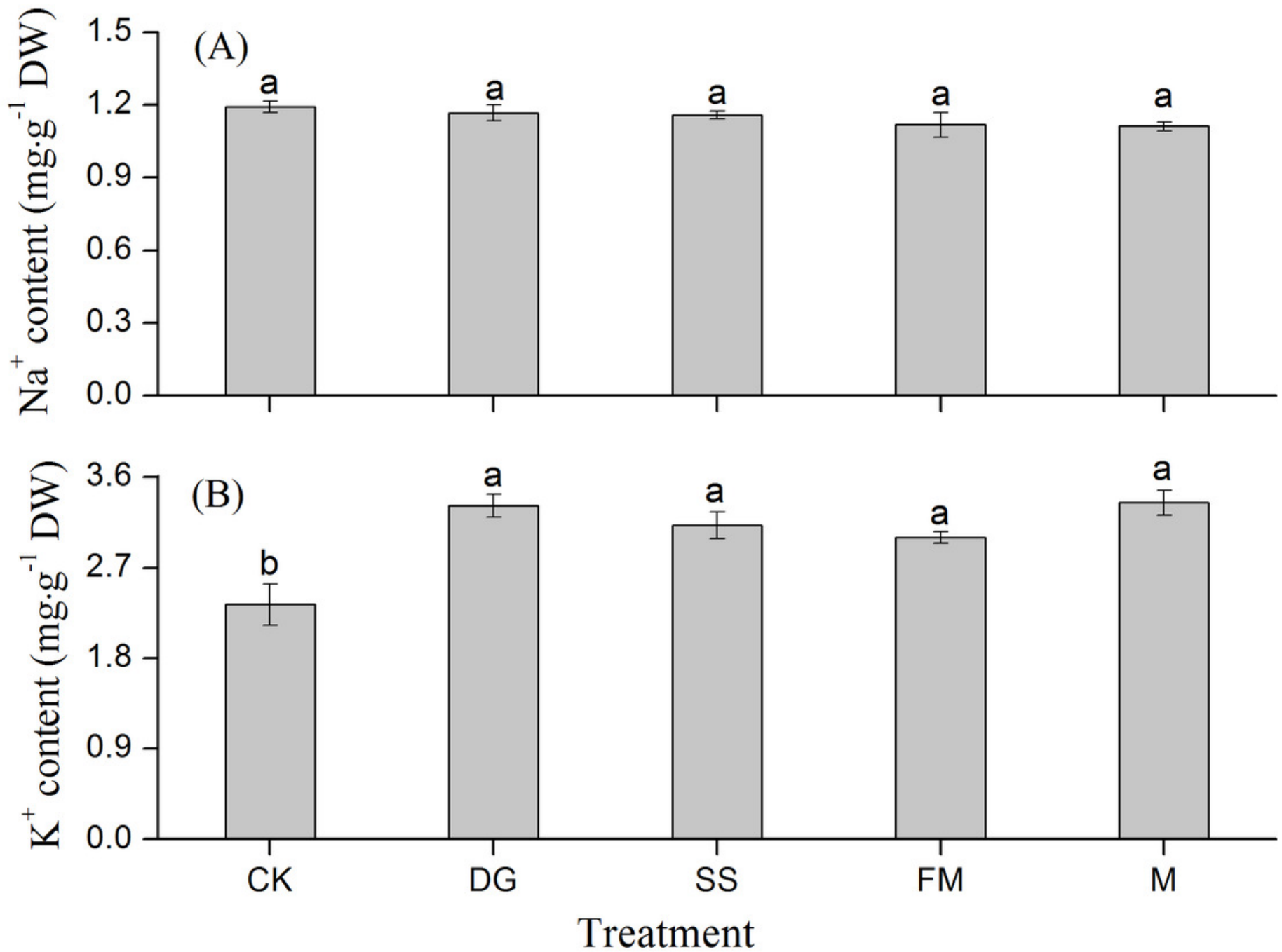


\section{Figure 6}

The trend of grain yield.

CK, control, without amendments application; DG, desulfurization gypsum; SS, sandy soil; FM, farmyard manure; $M$, mixture of desulfurization gypsum, sandy soil and farmyard manure. Bars represent the standard error of the mean of three replications.

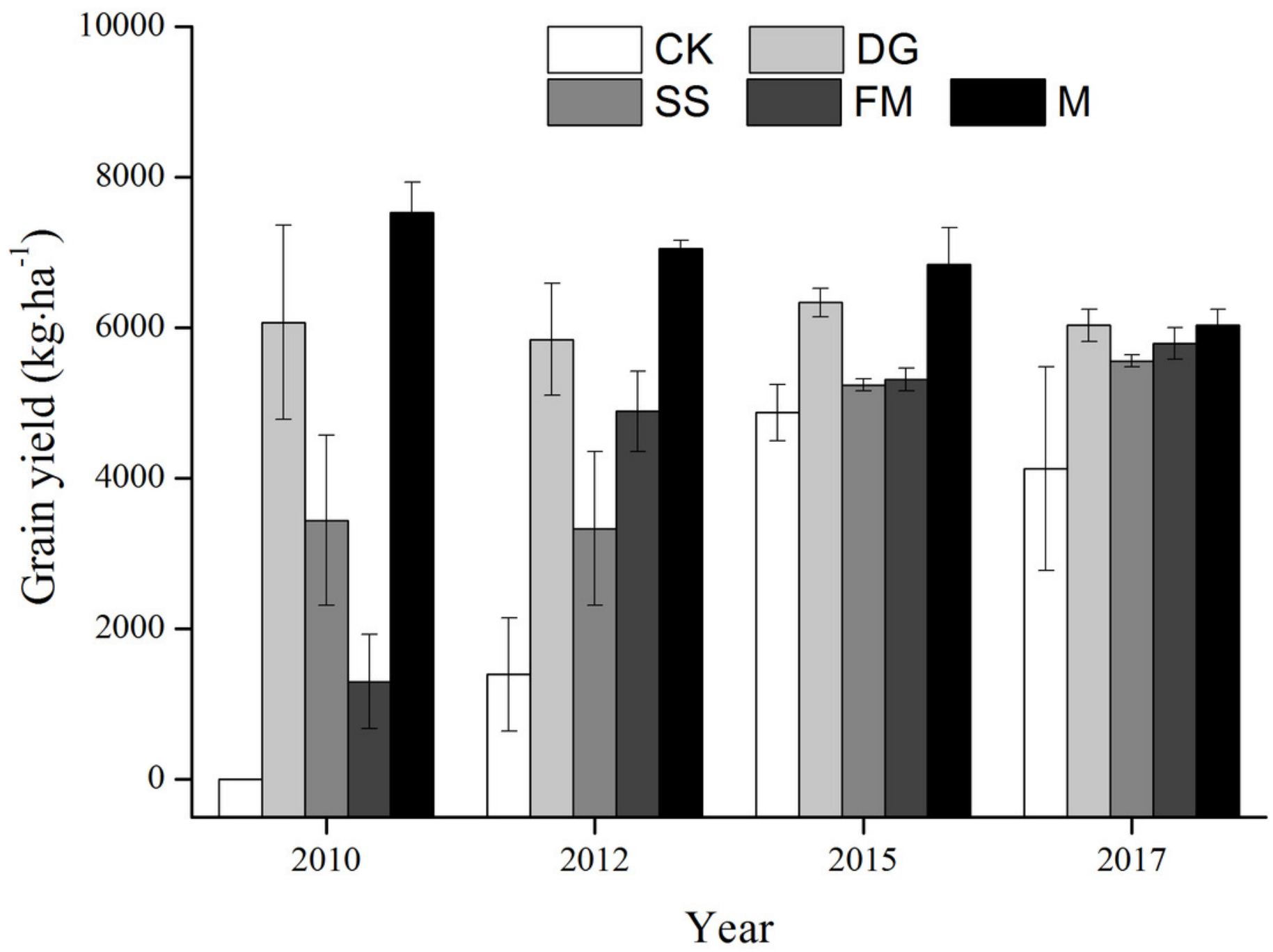




\section{Table $\mathbf{1}$ (on next page)}

Properties of the amendments used in the present study.

Note: EC, electrical conductivity; SOC, soil organic carbon. 
1 Table 1. Properties of the amendments used in the present study.

\begin{tabular}{llll}
\hline Property & Desulfurization gypsum & Sandy soil & Farm manure \\
\hline $\mathrm{pH}$ & 7.62 & 8.92 & 8.30 \\
$\mathrm{EC}(\mathrm{dS} / \mathrm{m})$ & 34.20 & 0.78 & - \\
$\mathrm{SOC}(\mathrm{g} / \mathrm{kg})$ & - & 4.23 & 263.30 \\
$\mathrm{~K}^{+}(\mathrm{g} / \mathrm{kg})$ & 1.00 & 0.001 & 13.60 \\
$\mathrm{Na}^{+}(\mathrm{g} / \mathrm{kg})$ & 1.59 & 0.008 & 4.11 \\
$\mathrm{Ca}^{2+}(\mathrm{g} / \mathrm{kg})$ & 265.30 & 0.10 & 7.49 \\
$\mathrm{Mg}^{2+}(\mathrm{g} / \mathrm{kg})$ & 1.68 & 0.01 & 10.20 \\
\hline
\end{tabular}

2 Note: EC, electrical conductivity; SOC, soil organic carbon.

3 


\section{Table 2 (on next page)}

$\mathrm{Na}^{+}$and $\mathrm{K}^{+}$concentrations and $\mathrm{K}^{+} / \mathrm{Na}^{+}$ratios in different organs of rice plant with various treatments.

Note: the small letters after data in a column for each treatment indicate that ion contents were significantly different at $P=0.05$. CK, control, without amendments application; DG, desulfurization gypsum; SS, sandy soil; FM, farmyard manure; M, mixture of desulfurization gypsum, sandy soil and farmyard manure. 
1 Table $2 . \mathrm{Na}^{+}$and $\mathrm{K}^{+}$concentrations and $\mathrm{K}^{+} / \mathrm{Na}^{+}$ratios in different organs of rice plant with various treatments.

\begin{tabular}{|c|c|c|c|c|}
\hline Treatment & Organ & $\mathrm{Na}^{+}(\mathrm{mg} / \mathrm{g} \mathrm{DW})$ & $\mathrm{K}^{+}(\mathrm{mg} / \mathrm{g} \mathrm{DW})$ & $\mathrm{K}^{+} / \mathrm{Na}^{+}$ \\
\hline \multirow[t]{4}{*}{$\mathrm{CK}$} & Grain & $0.53 \mathrm{c}$ & $2.75 \mathrm{ab}$ & $7.07 \mathrm{a}$ \\
\hline & Leaf & $1.38 \mathrm{~b}$ & $3.61 \mathrm{a}$ & $2.57 \mathrm{~b}$ \\
\hline & Sheath & $1.06 \mathrm{~b}$ & $1.99 \mathrm{~b}$ & $1.90 \mathrm{~b}$ \\
\hline & Root & $2.38 \mathrm{a}$ & $3.01 \mathrm{a}$ & $1.36 \mathrm{~b}$ \\
\hline \multirow[t]{4}{*}{ DG } & Grain & $0.25 \mathrm{~d}$ & $2.62 b$ & $10.61 \mathrm{a}$ \\
\hline & Leaf & $1.63 b$ & $5.06 \mathrm{a}$ & $3.18 \mathrm{~b}$ \\
\hline & Sheath & $1.30 \mathrm{c}$ & $4.42 \mathrm{a}$ & $3.40 \mathrm{~b}$ \\
\hline & Root & $2.02 \mathrm{a}$ & $3.04 \mathrm{~b}$ & $1.53 \mathrm{c}$ \\
\hline \multirow[t]{4}{*}{ SS } & Grain & $0.27 \mathrm{~d}$ & $2.69 \mathrm{c}$ & $10.11 \mathrm{a}$ \\
\hline & Leaf & $1.59 \mathrm{~b}$ & $4.93 a$ & $3.11 \mathrm{~b}$ \\
\hline & Sheath & $1.19 \mathrm{c}$ & $3.56 \mathrm{~b}$ & $2.93 b$ \\
\hline & Root & $2.21 \mathrm{a}$ & $2.57 \mathrm{c}$ & $1.28 \mathrm{c}$ \\
\hline \multirow[t]{4}{*}{ FM } & Grain & $0.19 \mathrm{~d}$ & $2.60 \mathrm{~b}$ & $15.15 b$ \\
\hline & Leaf & $1.61 \mathrm{~b}$ & $5.19 \mathrm{a}$ & $3.23 b$ \\
\hline & Sheath & $1.13 \mathrm{c}$ & $2.67 \mathrm{~b}$ & $2.40 \mathrm{a}$ \\
\hline & Root & $2.16 \mathrm{a}$ & $2.51 \mathrm{~b}$ & $1.25 \mathrm{~b}$ \\
\hline \multirow[t]{4}{*}{ M } & Grain & $0.24 \mathrm{c}$ & $2.61 \mathrm{~b}$ & $12.59 \mathrm{a}$ \\
\hline & Leaf & $1.27 \mathrm{~b}$ & $4.62 \mathrm{a}$ & $3.85 \mathrm{~b}$ \\
\hline & Sheath & $1.31 \mathrm{~b}$ & $4.65 a$ & $3.54 \mathrm{~b}$ \\
\hline & Root & $2.36 \mathrm{a}$ & $2.80 \mathrm{~b}$ & $1.21 \mathrm{c}$ \\
\hline
\end{tabular}

2 Note: the small letters after data in a column for each treatment indicate that ion contents were significantly

3 different at $P=0.05$. CK, control, without amendments application; DG, desulfurization gypsum; SS, sandy soil;

4 FM, farmyard manure; M, mixture of desulfurization gypsum, sandy soil and farmyard manure. 


\section{Table 3 (on next page)}

Effects of amendments application on growth and yield of rice plant in 2017.

Note: mean value and its standard error (SE) are reported. Different letters denote means that are significantly different from each other $(P<0.05)$. CK, control, without amendments application; DG, desulfurization gypsum; SS, sandy soil; FM, farmyard manure; $M$, mixture of desulfurization gypsum, sandy soil and farmyard manure. 
Table 3. Effects of amendments application on growth and yield of rice plant in 2017.

\begin{tabular}{llllll}
\hline Treatment & $\begin{array}{l}\text { Height } \\
(\mathrm{cm})\end{array}$ & $\begin{array}{l}\text { Panicle } \\
\text { length }(\mathrm{cm})\end{array}$ & $\begin{array}{l}\text { Number of grains } \\
\text { per panicle }\end{array}$ & $\begin{array}{l}1000 \text {-grain } \\
\text { weight }(\mathrm{g})\end{array}$ & $\begin{array}{c}\text { Grain yield } \\
(\mathrm{kg} / \mathrm{ha})\end{array}$ \\
\hline $\mathrm{CK}$ & $89.0 \pm 3.2 \mathrm{a}$ & $14.3 \pm 0.4 \mathrm{a}$ & $59.3 \pm 3.9 \mathrm{~b}$ & $19.4 \pm 0.6 \mathrm{~b}$ & $4130 \pm 1349.2 \mathrm{~b}$ \\
$\mathrm{DG}$ & $87.8 \pm 3.4 \mathrm{a}$ & $15.3 \pm 0.4 \mathrm{a}$ & $78.5 \pm 9.5 \mathrm{ab}$ & $21.7 \pm 0.6 \mathrm{ab}$ & $6030 \pm 209.9 \mathrm{a}$ \\
$\mathrm{SS}$ & $89.8 \pm 2.1 \mathrm{a}$ & $15.3 \pm 0.6 \mathrm{a}$ & $86.7 \pm 5.2 \mathrm{a}$ & $20.7 \pm 0.8 \mathrm{ab}$ & $5560 \pm 79.4 \mathrm{a}$ \\
FM & $94.2 \pm 1.1 \mathrm{a}$ & $14.3 \pm 0.3 \mathrm{a}$ & $68.9 \pm 8.4 \mathrm{ab}$ & $22.4 \pm 0.7 \mathrm{a}$ & $5790 \pm 209.9 \mathrm{a}$ \\
$\mathrm{M}$ & $92.5 \pm 2.6 \mathrm{a}$ & $14.3 \pm 0.3 \mathrm{a}$ & $78.2 \pm 4.6 \mathrm{ab}$ & $21.9 \pm 0.9 \mathrm{a}$ & $6030 \pm 209.9 \mathrm{a}$ \\
\hline
\end{tabular}

2 Note: mean value and its standard error (SE) are reported. Different letters denote means that are significantly

3 different from each other $(P<0.05)$. CK, control, without amendments application; DG, desulfurization gypsum;

4 SS, sandy soil; FM, farmyard manure; M, mixture of desulfurization gypsum, sandy soil and farmyard manure. 


\section{Table 4 (on next page)}

Correlation coefficients among OP, SA, ST values and different growth and yield of rice in 2017.

Note: $*$ and ${ }^{* *}$ denote correlation at the 0.05 and 0.01 levels of significance, respectively. 
Table 4. Correlation coefficients among OP, SA, ST values and different growth and yield of rice in 2017.

\begin{tabular}{|c|c|c|c|c|c|c|c|}
\hline & $\begin{array}{l}\mathrm{OP}_{\mathrm{SS}} \\
\text { (bars) }\end{array}$ & $\begin{array}{l}\text { SA } \\
\text { (selective } \\
\text { absorption) }\end{array}$ & $\begin{array}{l}\text { ST value } \\
\text { (selective transport) }\end{array}$ & $\begin{array}{l}\text { Height } \\
(\mathrm{cm})\end{array}$ & $\begin{array}{l}\text { Panicle } \\
\text { length }(\mathrm{cm})\end{array}$ & $\begin{array}{l}\text { Number of } \\
\text { grains per } \\
\text { panicle }\end{array}$ & $\begin{array}{l}\text { 1000-grain } \\
\text { weight }(\mathrm{g})\end{array}$ \\
\hline SA (selective absorption) & -0.857 & & & & & & \\
\hline ST (selective transport) & 0.628 & $-0.879^{*}$ & & & & & \\
\hline Height (cm) & 0.695 & -0.589 & 0.278 & & & & \\
\hline Panicle length $(\mathrm{cm})$ & -0.146 & -0.205 & 0.391 & -0.62 & & & \\
\hline $\begin{array}{l}\text { Number of grains per } \\
\text { panicle }\end{array}$ & 0.276 & -0.492 & 0.319 & -0.08 & 0.727 & & \\
\hline 1000-grain weight (g) & $0.992^{* *}$ & $-0.884^{*}$ & 0.671 & 0.619 & -0.024 & 0.375 & \\
\hline Grain yield (kg/ha) & 0.789 & $-0.925^{*}$ & 0.821 & 0.303 & 0.477 & 0.714 & 0.855 \\
\hline
\end{tabular}

